Brazilian Journal of Poultry Science Revista Brasileira de Ciência Avícola

\section{Glycerine Derived from Biodiesel Production as a Feedstuff for Broiler Diets}

\section{-Author(s)}

Silva $\mathrm{CLS}^{2}$

Menten JFM

Traldi $A B$

Pereira ${ }^{2} R$

Zavarize $^{2} \mathrm{KC}$

Santarosa ${ }^{2}$
1 Part of the M.Sc dissertation of the first author. Part of the results of this study were published in the 2010 APINCO Conference proceedings (Nutrition Section), Santos, SP, Brazil

Graduate students - Department of Animal Science - ESALQ/USP

${ }^{3}$ Head Professor of the Department of Animal Science - ESALQ/USP

\section{Mail Adress}

Camila Leão Silveira da Silva

Departamento de Zootecnia - ESALQ/USP

Avenida Pádua Dias, n¹1 - Agronomia -

Piracicaba - SP - CEP: 13418-900

E-mail: camilaleaos@yahoo.com.br

\section{-Keywords}

Alternative feedstuffs, broilers, biodiesel, performance, glycerol.
Submitted: October/2011

Approved: August/2012

\section{ABSTRACT}

The performance, carcass traits, and litter humidity of broilers fed increasing levels of glycerine derived from biodiesel production were evaluated. In this experiment, 1,575 broilers were distributed according to a completely randomized experimental design into five treatments with seven replicates of 45 birds each. Treatments consisted of a control diet and four diets containing $2.5,5.0,7.5$, or $10 \%$ glycerine. The experimental diets contained equal nutritional levels and were based on corn, soybean meal and soybean oil. The glycerine included in the diets contained $83.4 \%$ glycerol, $1.18 \%$ sodium, and 208 ppm methanol, and a calculated energy value of 3,422 kcal AMEn/kg. Performance parameters (weight gain, feed intake, feed conversion ratio, live weight, and livability) were monitored when broilers were 7,21 , and 42 days of age. On day 43 , litter humidity was determined in each pen, and 14 birds/treatment were sacrificed for the evaluation of carcass traits. During the period of 1 to 7 days, there was a positive linear effect of the treatments on weight gain, feed intake, and live weight gain. Livability linearly decreased during the period of 1 to 21 days. During the entire experimental period, no significant effects were observed on performance parameters or carcass traits, but there was a linear increase in litter humidity. Therefore, the inclusion of up to $5 \%$ glycerine in the diet did not affect broiler performance during the total rearing period.

\section{INTRODUCTION}

The denominations glycerine, glycerol, crude glycerine, and purified glycerine are often interchangeably used, but these compounds may be very different. The difference between the glycerine products available in the market is determined by the intensity of their industrial processing. They may be found in the crude (high fatty acid content), semi-purified (low fatty acid content), or in the purified form (pure compound). The by-product derived from biodiesel production has been called glycerol by some authors, while others call it glycerine. However, according to Morrison (1994), the term glycerol should be applied only to the pure compound (1,2,3-propanetriol), whereas the term glycerine refers to the purified commercial compounds.

Glycerine is the main co-product generated in the production of biodiesel. Approximately $10 \%$ of the total volume of biodiesel produced corresponds to glycerine (Dasari et al., 2005). According to the Brazilian Oil Agency, Brazil is among the largest global biodiesel producers and consumers, with an annual production in 2010 of 2.4 biodiesel millions liters, generating 240,000 tons of glycerine.

The use of glycerine in poultry and swine feed formulation may be interesting, as it is rich in energy $(4,320 \mathrm{kcal}$ gross energy per kg of pure glycerine) and presents high efficiency of utilization by animals. Another 
aspect that may justify the use of that co-product of the biodiesel industry in feed production is that part of the renewable raw materials used for energy purposes will return to the food chain, generating products with high nutritional value. In addition of being an energy source, glycerol may also have positive effect on amino acid or nitrogen retention, as mentioned by Cerrate et al. (2006).

The energy value of glycerine is a function of its proportion of pure glycerol (Lammers et al., 2007b). Research studies with broilers reported that the coefficient of metabolization of gross energy (GEMC) of glycerine products containing $85-90 \%$ glycerine range between 95\% (Dozier et al., 2008) and 85\% (Gianfelici, 2009; Oliveira et al., 2010), demonstrating that broilers utilize this feedstuff efficiently .

In Brazil, recent studies carried out with poultry (Gianfelici, 2009; Batista, 2010) and pigs (Berenchtein et al., 2010) showed that glycerine may be included in feeds, as it has high energy content and it is efficiently used by animals.

The objective of this study was to evaluate the influence on performance and carcass traits, as well as possible detrimental effects, of increasing levels of glycerine added as energy feedstuff in broiler diets.

\section{MATERIAL AND METHODS}

The study was carried out at the Department of Animal Science of ESALQ/USP, Piracicaba, SP, Brazil. A total number of 1,575 male Cobb 500 chicks, with $45.5 \mathrm{~g} \pm 3.3 \mathrm{~g}$ average initial weight, were distributed according to a completely randomized experimental design into five treatments with seven replicates of 45 birds each.

The basal diet was formulated to supply the broilers' nutritional requirements, according to the recommendations of Rostagno et al. (2005), and the other four treatments consisted in the dietary inclusion of 2.5, 5.0, 7.5, and 10\% glycerine. Glycerine was acquired from the company ADM do Brasil Ltda. and its concentration was analyzed in a commercial laboratory (Table 1). Glycerol concentration was determined by high-performance liquid chromatography (HPLC), with electro-chemical detection, according to the methodology adapted from Silva (2004) and Dionex Corporation (2006). The ingredient composition and the calculated nutritional values are presented in Tables $2,3,4$, and 5.

Glycerine gross energy value was determined as $3,602 \mathrm{kcal} / \mathrm{kg}$, using a calorimetric bomb. The determination of metabolizable energy was based on Dozier et al. (2008), who determined that the coefficient of metabolizability of glycerine gross energy is $95 \%$; therefore, the calculated metabolizable energy was $3,422 \mathrm{kcal} / \mathrm{kg}$. The apparent metabolizable energy value (AME) was based on the study of Dozier et al. (2008), because the composition of the glycerine products in both studies was similar. Diets were formulated taking into account glycerine sodium and chlorine levels.

\begin{tabular}{lcc}
\hline $\begin{array}{l}\text { Table } \mathbf{1} \text {-Composition of the crude glycerine included in } \\
\text { the diets }\end{array}$ & Unit & Results \\
\hline Analysis & $\%$ & 14.92 \\
\hline Humidity and volatile compounds & $\%$ & 83.4 \\
Glycerol & $\%$ & 0.09 \\
Total phosphorus & $\%$ & 1.18 \\
Sodium & $\%$ & 0.22 \\
Potassium & $\mathrm{mg} / \mathrm{L}$ & 208 \\
\hline Methanol & $\%$ & 1.3 \\
\hline Acidity & & \\
\hline
\end{tabular}

The feeding program applied during the experiment considered the following rearing phases: pre-starter, from 1 to 7 days, starter, from 7 to 21 days; grower, from 21 to 35 days, and finisher, from 35 to 42 days. Birds were offered feed and water ad libitum during the entire experimental period. Performance parameters (live weight, weight gain, feed intake, feed conversion ratio, and livability) were determined for each rearing phase.

On day 43, two birds per experimental unit (14 birds per treatment) were submitted to fasting for eight hours, and then sacrificed to determine carcass yield and parts (breast, drumstick + thighs, wings, and back) yield, and abdominal fat content. Litter material was collected from each pen to determine litter humidity.

Performance, carcass trait, and litter humidity data were submitted to analysis of variance (ANOVA), using the PROC MIXED of SAS (2006). When the effect of glycerine levels was significant $(p<0.05)$, degrees of freedom were decomposed into their individual components (linear and quadratic), using orthogonal polynomials by the PROC REG of SAS (Statistical Analysis System, 2006). 
Table 2 - Ingredient composition and calculated nutritional values of the pre-starter diets (1-7 days of age).

\begin{tabular}{|c|c|c|c|c|c|}
\hline \multirow{2}{*}{$\begin{array}{l}\text { Glycerine inclusion (\%) } \\
\text { Ingredients }\end{array}$} & \multirow[b]{2}{*}{0.0} & & & & \\
\hline & & 2.5 & 5.0 & 7.5 & 10.0 \\
\hline Ground corn & 54.50 & 51.76 & 49.00 & 46.26 & 43.52 \\
\hline Soybean meal & 38.59 & 38.89 & 39.21 & 39.51 & 39.82 \\
\hline Soybean oil & 2.39 & 2.39 & 2.39 & 2.39 & 2.39 \\
\hline Glycerine & 0.00 & 2.50 & 5.00 & 7.50 & 10.00 \\
\hline Dicalcium phosphate & 1.94 & 1.94 & 1.95 & 1.96 & 1.97 \\
\hline Limestone & 0.94 & 0.93 & 0.92 & 0.92 & 0.91 \\
\hline Salt & 0.52 & 0.44 & 0.37 & 0.29 & 0.22 \\
\hline DL-methionine & 0.38 & 0.37 & 0.38 & 0.38 & 0.39 \\
\hline L-lysine $\mathrm{HCl}$ & 0.34 & 0.34 & 0.34 & 0.33 & 0.33 \\
\hline L-threonine & 0.14 & 0.14 & 0.14 & 0.15 & 0.15 \\
\hline Vitamin supplement $^{1}$ & 0.10 & 0.10 & 0.10 & 0.10 & 0.10 \\
\hline Choline chloride $60 \%$ & 0.08 & 0.08 & 0.08 & 0.08 & 0.08 \\
\hline Anticoccidial agent ${ }^{2}$ & 0.05 & 0.05 & 0.05 & 0.05 & 0.05 \\
\hline Mineral supplement ${ }^{3}$ & 0.05 & 0.05 & 0.05 & 0.05 & 0.05 \\
\hline Growth promoter & 0.005 & 0.005 & 0.005 & 0.005 & 0.005 \\
\hline \multicolumn{6}{|l|}{ Calculated values } \\
\hline ME (kcal/kg) & 2.960 & 2.960 & 2.960 & 2.960 & 2.960 \\
\hline $\mathrm{CP}(\%)$ & 22.63 & 22.54 & 22.46 & 22.38 & 22.29 \\
\hline Dig. Met + Cystine (\%) & 0.97 & 0.97 & 0.97 & 0.97 & 0.97 \\
\hline Dig. methionine (\%) & 0.67 & 0.67 & 0.67 & 0.67 & 0.67 \\
\hline Dig. lysine (\%) & 1.37 & 1.37 & 1.37 & 1.37 & 1.37 \\
\hline Dig. threonine & 0.89 & 0.89 & 0.89 & 0.89 & 0.89 \\
\hline Dig. tryptophan (\%) & 0.24 & 0.24 & 0.24 & 0.24 & 0.24 \\
\hline Dig. valine (\%) & 0.93 & 0.93 & 0.92 & 0.92 & 0.92 \\
\hline Dig. phenylalanine (\%) & 1.02 & 1.02 & 1.01 & 1.01 & 1.00 \\
\hline Calcium (\%) & 0.94 & 0.94 & 0.94 & 0.94 & 0.94 \\
\hline Available phosphorus (\%) & 0.47 & 0.47 & 0.47 & 0.47 & 0.47 \\
\hline Sodium (\%) & 0.22 & 0.22 & 0.22 & 0.22 & 0.22 \\
\hline
\end{tabular}

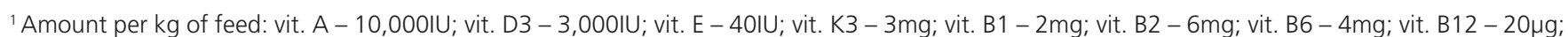
nicotinic acid - 40mg; pantothenic acid - 12mg; biotin-0.15mg; folic acid-1mg; selenium- $0.25 \mathrm{mg}$

${ }^{2}$ Coxistac $-12 \%$ salinomycin.

${ }^{3}$ Amount per kg of feed: manganese $-80 \mathrm{mg}$; iron $-50 \mathrm{mg}$; zinc $-50 \mathrm{mg}$; copper $-10 \mathrm{mg}$; cobalt $-1 \mathrm{mg}$; iodine $-1 \mathrm{mg}$

${ }^{4}$ Halquinol BP80 - 98\% chloro-hydroxy-quinoline 
Table 3 - Ingredient composition and calculated nutritional values of the starter diets (7-21 days of age).

\begin{tabular}{|c|c|c|c|c|c|}
\hline \multirow[b]{2}{*}{ Ingredients } & \multicolumn{5}{|c|}{ Glycerine inclusion (\%) } \\
\hline & 0.0 & 2.5 & 5.0 & 7.5 & 10.0 \\
\hline Ground corn & 57.31 & 54.26 & 51.21 & 48.16 & 45.11 \\
\hline Soybean meal $45 \%$ & 35.29 & 35.86 & 36.44 & 37.01 & 37.56 \\
\hline Soybean oil & 3.32 & 3.38 & 3.43 & 3.49 & 3.55 \\
\hline Glycerine & 0.00 & 2.50 & 5.00 & 7.50 & 10.00 \\
\hline Dicalcium phosphate & 1.84 & 1.84 & 1.85 & 1.86 & 1.87 \\
\hline Limestone & 0.90 & 0.90 & 0.89 & 0.88 & 0.88 \\
\hline Salt & 0.50 & 0.43 & 0.36 & 0.28 & 0.21 \\
\hline DL-methionine & 0.27 & 0.27 & 0.28 & 0.28 & 0.28 \\
\hline L-lysine $\mathrm{HCl}$ & 0.21 & 0.21 & 0.21 & 0.21 & 0.21 \\
\hline L-threonine & 0.07 & 0.07 & 0.07 & 0.06 & 0.06 \\
\hline Vitamin supplement ${ }^{1}$ & 0.10 & 0.10 & 0.10 & 0.10 & 0.10 \\
\hline Choline chloride $60 \%$ & 0.08 & 0.08 & 0.08 & 0.08 & 0.08 \\
\hline Anticoccidial agent ${ }^{2}$ & 0.05 & 0.05 & 0.05 & 0.05 & 0.05 \\
\hline Mineral supplement ${ }^{3}$ & 0.05 & 0.05 & 0.05 & 0.05 & 0.05 \\
\hline Growth promoter ${ }^{4}$ & 0.005 & 0.005 & 0.005 & 0.005 & 0.005 \\
\hline \multicolumn{6}{|l|}{ Calculated values } \\
\hline ME (kcal/kg) & 3.050 & 3.050 & 3.050 & 3.050 & 3.050 \\
\hline $\mathrm{CP}(\%)$ & 21.14 & 21.14 & 21.14 & 21.14 & 21.14 \\
\hline Dig. Met + Cystine (\%) & 0.84 & 0.84 & 0.84 & 0.84 & 0.84 \\
\hline Dig. methionine (\%) & 0.56 & 0.56 & 0.56 & 0.56 & 0.56 \\
\hline Dig. lysine (\%) & 1.18 & 1.18 & 1.18 & 1.18 & 1.18 \\
\hline Dig. threonine (\%) & 0.77 & 0.77 & 0.77 & 0.77 & 0.77 \\
\hline Dig. tryptophan (\%) & 0.23 & 0.23 & 0.23 & 0.23 & 0.23 \\
\hline Dig. valine (\%) & 0.88 & 0.88 & 0.88 & 0.88 & 0.88 \\
\hline Calcium (\%) & 0.89 & 0.89 & 0.89 & 0.89 & 0.89 \\
\hline Available phosphorus (\%) & 0.45 & 0.45 & 0.45 & 0.45 & 0.45 \\
\hline Sodium (\%) & 0.22 & 0.22 & 0.22 & 0.22 & 0.22 \\
\hline \multicolumn{6}{|c|}{ 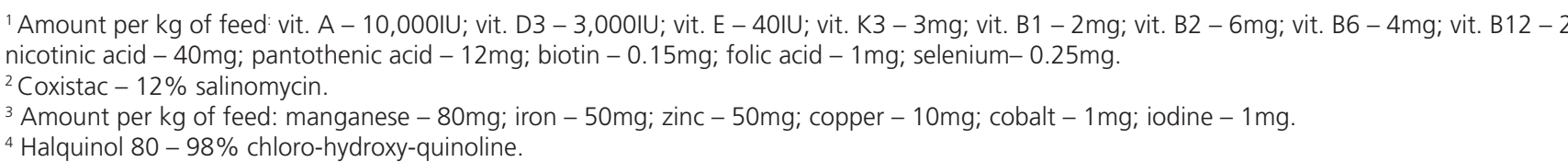 } \\
\hline
\end{tabular}


Table 4 - Ingredient composition and calculated nutritional values of the grower diets (21-35 days of age).

\begin{tabular}{|c|c|c|c|c|c|}
\hline \multirow[b]{2}{*}{ Ingredients } & \multicolumn{5}{|c|}{ Glycerine inclusion (\%) } \\
\hline & 0.0 & 2.5 & 5.0 & 7.5 & 10.0 \\
\hline Ground corn & 60.00 & 56.95 & 53.90 & 50.85 & 47.86 \\
\hline Soybean meal 45\% & 31.75 & 32.32 & 32.90 & 33.47 & 34.04 \\
\hline Soybean oil & 4.35 & 4.41 & 4.46 & 4.5 & 4.56 \\
\hline Glycerine & 0.00 & 2.50 & 5.00 & 7.50 & 10.00 \\
\hline Dicalcium phosphate & 1.69 & 1.70 & 1.71 & 1.71 & 1.72 \\
\hline Limestone & 0.85 & 0.85 & 0.84 & 0.8 & 0.83 \\
\hline Sodium bicarbonate & 0.36 & 0.36 & 0.36 & 0.36 & 0.27 \\
\hline Salt & 0.23 & 0.16 & 0.08 & 0.01 & 0.00 \\
\hline DL-methionine & 0.25 & 0.25 & 0.24 & 0.26 & 0.26 \\
\hline L-lysine $\mathrm{HCl}$ & 0.21 & 0.20 & 0.19 & 0.18 & 0.17 \\
\hline L-threonine & 0.05 & 0.05 & 0.05 & 0.05 & 0.05 \\
\hline Choline chloride $60 \%$ & 0.06 & 0.06 & 0.06 & 0.06 & 0.06 \\
\hline Vitamin supplement $^{1}$ & 0.08 & 0.08 & 0.08 & 0.08 & 0.08 \\
\hline Mineral supplement ${ }^{2}$ & 0.05 & 0.05 & 0.05 & 0.05 & 0.05 \\
\hline Anticoccidial agent ${ }^{3}$ & 0.05 & 0.05 & 0.05 & 0.05 & 0.05 \\
\hline Growth promoter ${ }^{4}$ & 0.005 & 0.005 & 0.005 & 0.005 & 0.005 \\
\hline \multicolumn{6}{|l|}{ Calculated values } \\
\hline ME (kcal/kg) & 3.150 & 3150 & 3.150 & 3.150 & 3.150 \\
\hline $\mathrm{CP}(\%)$ & 19.73 & 19.73 & 19.73 & 19.73 & 19.73 \\
\hline Dig. Met + Cystine (\%) & 0.79 & 0.79 & 0.79 & 0.79 & 0.79 \\
\hline Dig. methionine (\%) & 0.52 & 0.52 & 0.52 & 0.53 & 0.53 \\
\hline Dig. lysine (\%) & 1.09 & 1.09 & 1.09 & 1.09 & 1.09 \\
\hline Dig. threonine (\%) & 0.71 & 0.71 & 0.71 & 0.71 & 0.71 \\
\hline Dig. tryptophan & 0.21 & 0.21 & 0.21 & 0.21 & 0.21 \\
\hline Dig. valine (\%) & 0.82 & 0.82 & 0.82 & 0.82 & 0.82 \\
\hline calcium & 0.84 & 0.84 & 0.84 & 0.84 & 0.84 \\
\hline Available phosphorus (\%) & 0.42 & 0.42 & 0.42 & 0.42 & 0.42 \\
\hline Sodium (\%) & 0.21 & 0.21 & 0.21 & 0.21 & 0.21 \\
\hline
\end{tabular}

${ }^{1}$ Amount per $\mathrm{kg}$ of feed vit. A - 8,000IU; vit. D3 - 2,400IU; vit. E - 32IU; vit. K3 - 2.4mg; vit. B1 - 1.6mg; vit. B2 - 4.8mg; vit. B6 - 3.2mg; vit.

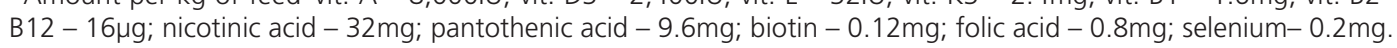

${ }^{2}$ Amount per $\mathrm{kg}$ of feed manganese $-80 \mathrm{mg}$; iron $-50 \mathrm{mg}$; zinc $-50 \mathrm{mg}$; copper $-10 \mathrm{mg}$; cobalt $-1 \mathrm{mg}$; iodine $-1 \mathrm{mg}$

${ }^{3}$ Coxistac $-12 \%$ Salinomycin. ${ }^{4}$ Halquinol $80-98 \%$ chloro-hydroxy-quinoline 
Table 5 - Ingredient composition and calculated nutritional values of the finisher diets (35-42 days of age).

\begin{tabular}{|c|c|c|c|c|c|}
\hline \multirow[b]{2}{*}{ Ingredients } & \multicolumn{5}{|c|}{ Glycerine inclusion (\%) } \\
\hline & 0.0 & 2.5 & 5.0 & 7.5 & 10.0 \\
\hline Ground corn & 64.47 & 61.43 & 58.37 & 55.34 & 52.35 \\
\hline Soybean meal $45 \%$ & 27.65 & 28.23 & 28.80 & 29.37 & 29.94 \\
\hline Soybean oil & 4.22 & 4.28 & 4.33 & 4.38 & 4.42 \\
\hline Glycerine & 0.00 & 2.50 & 5.00 & 7.50 & 10.00 \\
\hline Dicalcium phosphate & 1.54 & 1.55 & 1.55 & 1.56 & 1.57 \\
\hline Limestone & 0.81 & 0.80 & 0.80 & 0.79 & 0.79 \\
\hline Sodium bicarbonate & 0.35 & 0.35 & 0.35 & 0.32 & 0.24 \\
\hline Salt & 0.21 & 0.14 & 0.07 & 0.02 & 0.00 \\
\hline DL-methionine & 0.24 & 0.24 & 0.25 & 0.25 & 0.25 \\
\hline L-lysine $\mathrm{HCl}$ & 0.27 & 0.26 & 0.25 & 0.24 & 0.23 \\
\hline L-threonine & 0.07 & 0.07 & 0.07 & 0.07 & 0.07 \\
\hline Vitamin supplement $^{1}$ & 0.06 & 0.06 & 0.06 & 0.06 & 0.06 \\
\hline Mineral supplement ${ }^{2}$ & 0.05 & 0.05 & 0.05 & 0.05 & 0.50 \\
\hline Choline chloride $60 \%$ & 0.040 & 0.040 & 0.040 & 0.040 & 0.040 \\
\hline \multicolumn{6}{|l|}{ Calculated values } \\
\hline ME (kcal/kg) & 3.200 & 3.200 & 3.200 & 3.200 & 3.200 \\
\hline $\mathrm{CP}(\%)$ & 18.31 & 18.31 & 18.31 & 18.31 & 18.31 \\
\hline Dig. Met + Cystine (\%) & 0.76 & 0.76 & 0.76 & 0.76 & 0.76 \\
\hline Dig. methionine (\%) & 0.50 & 0.50 & 0.50 & 0.50 & 0.51 \\
\hline Dig. lysine (\%) & 1.05 & 1.05 & 1.05 & 1.05 & 1.05 \\
\hline Dig. threonine & 0.68 & 0.68 & 0.68 & 0.68 & 0.68 \\
\hline Dig. tryptophan & 0.19 & 0.19 & 0.19 & 0.19 & 0.19 \\
\hline Dig. valine (\%) & 0.75 & 0.75 & 0.76 & 0.76 & 0.76 \\
\hline calcium & 0.77 & 0.77 & 0.77 & 0.77 & 0.77 \\
\hline Available phosphorus (\%) & 0.38 & 0.38 & 0.38 & 0.38 & 0.38 \\
\hline Sodium (\%) & 0.19 & 0.19 & 0.19 & 0.19 & 0.19 \\
\hline
\end{tabular}

${ }^{1}$ Amount per kg of feed: vit. A - 6,000IU; vit. D3 - 1,800IU; - 24IU; vit. K3-1.8mg; vit. B1 - 1.2mg; vit. B2 - 3.6mg; vit. B6 - 2.4mg; vit. B12-12 $\mu \mathrm{g}$; nicotinic acid - 24mg; pantothenic acid $-7.2 \mathrm{mg}$; biotin $-0.09 \mathrm{mg}$; folic acid $-0.6 \mathrm{mg}$; selenium $-0.15 \mathrm{mg}$.

${ }_{2}^{2}$ Amount per $\mathrm{kg}$ of feed: manganese $-80 \mathrm{mg}$; iron $-50 \mathrm{mg}$; zinc $-50 \mathrm{mg}$; copper $-10 \mathrm{mg}$; cobalt $-1 \mathrm{mg}$; iodine $-1 \mathrm{mg}$ 


\section{RESULTS AND DISCUSSION}

The inclusion of increasing glycerine levels in the diet of broilers during the period of 1 to 7 days of age linearly increased $(p<0.05)$ their live weight, weight gain, and feed intake. However, there was no effect $(p>0.05)$ on feed conversion ratio or livability (Table 5).

Table 6 - Means, analysis of variance and analysis of regression of the live weight at 7 days (LW), daily weight gain (WG), feed intake (FI), feed conversion ratio (FCR), and livability of broilers between 1 and 7 days of age.

\begin{tabular}{llllll}
\hline $\begin{array}{l}\text { Glycerine } \\
\text { inclusion (\%) }\end{array}$ & \multicolumn{5}{c}{ Parameters } \\
\cline { 2 - 6 }$(\%)$ & LW (g) & WG (g) & Fl (g) & FCR & L (\%) \\
\hline 0.0 & 199.2 & 152.7 & 166.7 & 1.092 & 100 \\
\hline 2.5 & 196.6 & 150.4 & 162.3 & 1.080 & 100 \\
\hline 5.0 & 209.3 & 162.3 & 169.7 & 1.047 & 99.6 \\
\hline 7.5 & 210.8 & 164.3 & 171.2 & 1.042 & 98.7 \\
\hline 10.0 & 211.3 & 165.1 & 176.6 & 1.070 & 99.6 \\
\hline P value & 0.0002 & 0.0002 & 0.0005 & 0.1162 & 0.3201 \\
\hline Linear regression & 0.0002 & 0.0001 & 0.0004 & NS & NS \\
\hline Quadratic regression & NS & NS & NS & NS & NS \\
\hline CV (\%) & 3.68 & 4.56 & 3.61 & 2.72 & 1.26 \\
\hline
\end{tabular}

CV (\%) - coefficient of variation; NS - non-significant effect ( $p>0.05)$.

$\mathrm{LW}=1.536 \mathrm{X}+197.8 ; \mathrm{R}^{2}=0.76$

$W G=1.546 X+151.3 ; R^{2}=0.79$

$\mathrm{FI}=1.144 \mathrm{X}+163.3 ; \mathrm{R}^{2}=0.73$

The inclusion of up to $10 \%$ glycerine in the diet during the period of 1 to 7 days of age positively influenced broiler live weight, weight gain, and feed intake. As compared to mammals, bird taste and smell are not well developed, and these deficiencies are compensated by mechanic receptors located in the peak. These receptor cells are stimulated by direct contact with the feed, similarly as the stimulus elicited by smell and taste in mammals (Berkhoudt, 1984). The dietary inclusion of glycerine in mash diets may improve feed texture and palatability, in addition of reducing dust, therefore increasing feed intake. In young broilers (1 to 21 days of age), feed texture has a marked effect on feed intake, and consequently, on weight gain (Bueno, 2006).
Consistent findings were observed with the inclusion of $4 \%$ glycerine in broiler diets during the first week of age (Fernandes et al., 2010) and with 6\% dietary glycerine inclusion in nursery pigs (Groesbeck et al., 2008). Both authors attributed these results to better feed palatability. Some glycerine characteristics, such as acidity, should be taken into account in research studies, as they may directly interfere in glycerine quality, and possibly affect feed intake.

The performance results obtained for the period of 1 to 21 days of age are presented in Table 7 . Livability was linearly reduced $(p<0.05)$, whereas feed conversion ratio was not affected $(p>0.05)$. There was a significant effect of treatments $(p<0.05)$ on feed intake, live weight, and weight gain, but no linear or quadratic trends were identified for glycerine levels. It was clear, however, that up to 21 days of age, the higher dietary glycerine levels did not have a negative influence on the performance parameters and that the $5 \%$ inclusion was the most beneficial for performance.

Table 7 - Means, analysis of variance and of regression of the live weight at 21 days (LW), daily weight gain (WG), feed intake (FI), feed conversion ratio (FCR), and livability of broilers between 1 and 21 days of age.

\begin{tabular}{|c|c|c|c|c|c|}
\hline \multirow{2}{*}{$\begin{array}{l}\text { Glycerine } \\
\text { inclusion (\%) } \\
(\%)\end{array}$} & \multicolumn{5}{|c|}{ Parameters } \\
\hline & LW (g) & WG (g) & $\mathrm{Fl}(\mathrm{g})$ & FCR & L (\%) \\
\hline 0.0 & 1011 & 963 & 1337 & 1.388 & 99.05 \\
\hline 2.5 & 1015 & 969 & 1323 & 1.365 & 99.05 \\
\hline 5.0 & 1044 & 997 & 1352 & 1.355 & 97.17 \\
\hline 7.5 & 1016 & 968 & 1352 & 1.398 & 96.70 \\
\hline 10.0 & 1026 & 980 & 1341 & 1.368 & 97.15 \\
\hline$P$ value & 0.0277 & 0.0223 & 0.0209 & 0.0584 & 0.0064 \\
\hline Linear regression & NS & NS & NS & NS & 0.0049 \\
\hline $\begin{array}{l}\text { Quadratic } \\
\text { regression }\end{array}$ & NS & NS & NS & NS & NS \\
\hline CV (\%) & 2.27 & 2.18 & 1.47 & 2.37 & 1.97 \\
\hline
\end{tabular}

${ }^{1}$ Coefficient of variation; NS - non-significant effect ( $p>0.05$ ) $L=-0.244 X+98.6 ; R^{2}=0.68$

The feed intake of broilers fed 5 and $7.5 \%$ glycerine during the period of 1 to 21 days of age was similar, but the inclusion of $5 \%$ glycerine promoted higher weight gain, while feed conversion ratio was similar 
among treatments. Consequently, the broilers fed $5 \%$ glycerine presented $3.3 \%$ higher weight gain at the end of the 21-d period compared with the control treatment. However, livability linearly decreased with glycerine inclusion levels.

Other studies reported that the inclusion of 10\% purified (Fernandes et al., 2010) or crude (Simon et al., 1997) glycerine did not influence broiler performance until 21 days of age.

During the period of 1 to 42 days of age, treatments did not influence performance parameters (Table 8). Despite the lack of statistical significance, the weight gain of broilers fed $10 \%$ glycerine was reduced in 131 $\mathrm{g}$ relative to the control birds, which represents a $4.2 \%$ difference in weight gain. Cerrate et al. (2006) fed $10 \%$ glycerine to broilers and reported a $5.75 \%$ (2871 vs. $2706 \mathrm{~g}$ ) reduction in final body weight.
Litter humidity, determined when broilers were 43 days of age, linearly increased $(p<0.05)$ as dietary glycerine levels increased (Table 9 ). Consistent results of increased litter moisture due to higher excreta moisture were obtained in Japanese quails (Batista, 2010), layers (Lammers et al., 2008), and broilers (Gianfelici, 2009). However, in all these studies, glycerine sodium levels were not considered in feed formulation and possibly exceeded the sodium nutritional recommendations for those animals.

When glycerine sodium levels are taken into account, the increase in excreta humidity may be explained by the hygroscopic properties of glycerol. When there is excessive glycerol in the body, water that should be reabsorbed binds to glycerol, and both are filtered in the kidneys and eliminated in the urine (Lin, 1977). This probably increases water consumption by

Table 8 - Live weight (LW), daily weight gain (WG), feed intake (FI), feed conversion ratio (FCR), and livability means of broilers between 1 and 42 days of age.

\begin{tabular}{|c|c|c|c|c|c|c|}
\hline \multirow{2}{*}{$\begin{array}{l}\text { Glycerine } \\
\text { inclusion } \\
\text { (\%) }\end{array}$} & \multicolumn{5}{|c|}{ Parameters } & \multirow{2}{*}{$\begin{array}{l}\text { Litter } \\
\text { humidity }\end{array}$} \\
\hline & $\operatorname{LW}(\mathrm{g})$ & WG (g) & $\mathrm{Fl}(\mathrm{g})$ & $\mathrm{FCR}$ & L (\%) & \\
\hline 0.0 & 3207 & 3170 & 5348 & 1.686 & 95.5 & 32.8 \\
\hline 2.5 & 3174 & 3117 & 5208 & 1.671 & 94.9 & 38.8 \\
\hline 5.0 & 3190 & 3132 & 5275 & 1.684 & 93.9 & 35.4 \\
\hline 7.5 & 3186 & 3131 & 5324 & 1.700 & 93.6 & 38.3 \\
\hline 10.0 & 3091 & 3039 & 5144 & 1.692 & 92.0 & 43.5 \\
\hline$P$ value & 0.2407 & 0.1273 & 0.0910 & 0.2388 & 0.1801 & 0.0009 \\
\hline Linear regression & NS & NS & NS & NS & NS & 0.0011 \\
\hline Quadratic regression & NS & NS & NS & NS & NS & NS \\
\hline $\mathrm{CV}^{\prime}(\%)$ & 3.13 & 2.92 & 2.95 & 1.42 & 2.78 & 12.95 \\
\hline $\begin{array}{l}{ }^{1} \text { Coefficient of variati } \\
\mathrm{HU}=0.836 \mathrm{X}+33.56\end{array}$ & & & & & & \\
\hline
\end{tabular}

Out of the total reduction in livability, $65 \%$ were attributed to mortality and 35\% to culling. The causes of culling during the entire experimental period were possibly derived from hatchery problems (lack of uniformity) and leg problems.

The dietary inclusion of $10 \%$ glycerine during the entire rearing period did not affect performance; however, LW tended to decrease. Other authors, working with dietary glycerine inclusions of $8 \%$ in broilers (Fernandes et al., 2010) and $10 \%$ in pigs (Berenchtein, 2008; Lammers et al., 2008), did not observe any performance impairment. the animals, because the water that should have been reutilized by the body is being eliminated together with glycerol. This assumption is supported by the study of Gianfelici (2009), who reported that broilers were able to metabolize diets containing up to $7.5 \%$ glycerol; above this level, there was an increase in free glycerol in the blood and in the excreta, as well as in water consumption.

Table 9 presents the carcass trait results of broilers at 43 days of age. Although breast yield increased $1.73 \%$ (4.5\% variation), no significant differences ( $p>0.05)$ were detected with the dietary inclusion of 
increasing glycerine levels. Other carcass traits were also not significantly influenced $(p>0.05)$ by the treatments. Consistent findings were obtained when up to $10 \%$ pure glycerol was included in the diet of one- to 35-d-old broilers (Gianfelici, 2009).

These results are different from the findings of Cerrate (2006), who detected a significant increase $(p<0.05)$ of $3 \%$ in the breast yield of broilers fed 2.5 and $5 \%$ glycerine in the diet, suggesting that glycerol

Table 9 - Means and analysis of variance of carcass yield $(C Y)$, breast yield $(B Y)$, drumstick and thighs yield (LY), wing yield (WY) and abdominal fat (AF) of 43-d-old broilers.

\begin{tabular}{|c|c|c|c|c|c|}
\hline \multirow{2}{*}{$\begin{array}{l}\text { Inclusion } \\
\text { Glycerine }\end{array}$} & \multicolumn{5}{|c|}{ Carcass traits } \\
\hline & CY (\%) & BY (\%) & LY (\%) & $\begin{array}{l}W Y \\
(\%)\end{array}$ & $A F(g)$ \\
\hline 0.0 & 74.14 & 37.97 & 30.19 & 10.81 & 50.67 \\
\hline 2.5 & 73.46 & 37.92 & 31.07 & 11.07 & 54.10 \\
\hline 5.0 & 73.66 & 38.18 & 30.60 & 11.16 & 55.35 \\
\hline 7.5 & 73.11 & 38.69 & 29.87 & 10.94 & 57.93 \\
\hline 10.0 & 73.62 & 39.70 & 30.29 & 11.28 & 47.61 \\
\hline$P$ value & 0.7909 & 0.2238 & 0.4002 & 0.5695 & 0.3271 \\
\hline Linear regression & NS & NS & NS & NS & NS \\
\hline $\begin{array}{l}\text { Quadratic } \\
\text { regression }\end{array}$ & NS & NS & NS & NS & NS \\
\hline $\mathrm{CV}^{1}(\%)$ & 2.82 & 5.68 & 5.40 & 6.95 & 25.79 \\
\hline
\end{tabular}

may increase breast protein deposition as it reduces gluconeogenesis from amino acids by inhibiting some enzymes, such as phosphoenolpiruvate carboxykinase.

\section{CONCLUSIONS}

Broiler performance and litter humidity is not affected with up to $5 \%$ glycerine is included in the diet during the entire rearing period.

\section{ACKNOWLEDGEMENTS}

The authors thank FAPESP for the grant given to the first author and the company ADM do Brasil for the funding provided for the development of this project.

\section{REFERENCES}

Agência Nacional de Petróleo [cited 2011 Set 20]. Disponível em: http:// www.anp.gov.br.

Batista E. Avaliação nutricional para codornas de corte [dissertação] Maringá (PR): Universidade Estadual de Maringá; 2010.

Berkhoudt, H.A. Structure and function of avian teste receptors.In: King AS, Mclelland $\mathrm{K}$, editors. Form and Functions in birds. London:Academic Press; 1984. p. 213-325.

Bueno FL. Efeito da forma física, granulometria (DGM) e adição de óleo em dietas 317 iniciais de frangos [dissertação]. Curitiba (PR); Universidade Federal do Paraná; 2006.

Berenchtein B. Utilização de glicerol na dieta de suínos em crescimento e terminação [dissertação]. Piracicaba (SP): Escola Superior de Agricultura "Luiz de Queiroz", Universidade de São Paulo; 2008.

Cerrate S, Yan F, Wang Z, Coto C, Sacakli P, Waldroup PW. Evaluation of glycerine from biodiesel production as a feed ingredient for broilers. International Journal of Pountry Science 2006; 5:1001-1007.

Dasari MA, Kiatsimkul PP, Sutterlin WR. Low-pressure hydrogenolysis of glycerol to propylene glycol. Applied Catalysis. A. General 2005 281:225-231

Dionex Corporation. The determination of carbohydrates, alcohols, and glycols in fermentation broths [Application Note 122]. Sunnyvale, CA 2006

Dozier III WA, Kerr BJ, Corzo A, Kidd MT, Weber TE, Bregendahl K. Apparent metabolizable energy of glycerin for broiler chickens. Poultry Science 2008;87:317-322.

Fernandes EA, Machado CA, Fagundes NS, França AMS, Ramos GC. Inclusão de glicerol purificado em dietas de frangos de corte [cd-rom] Anais da Conferência Apinco de Ciência e Tecnologia Avícola; 2010 Santos, SP. Brasil. Campinas: FACTA; 2010.

Gianfelici MF. Uso de glicerol como fonte de energia para frangos de corte [dissertação]. Porto Alegre (RS): Universidade Federal do Rio Grande do Sul; 2009.

Groesbeck CN, Mckinney LJ, Derouchey JM, Tokach MD, Goodband RD Ditriz SS, Nelssen JL, Duttlinger AW, Fahrenholz AC, Behnke KC. Effect of crude glycerol on pellet mill production and nursery pig growth performance. Journal of Animal Science 2008;86:2228-2236.

Lammers PJ, Kerr BJ, Honeyman MS, Stalder K, Dozier III WA, Weber TE Kidd MT, Bregendahl K. Nitrogen-corrected apparent metabolizable energy value of crude glycerol for laying hens. Poultry Science 288b;87:104-107.

Lin EC. Glycerol utilization and its regulation in mammals. Annual Review of Biochemistry 1997;46:765-795.

MORRISON LR. Glycerol. In: Encyclopedia of Chemical Technology. New York: Wiley; 1994. p. 921-932.

Rostagno HS, Albino LFT, Donzele JL, Gomes PC, Oliveira RF, Lopes DC, Ferreira AS, Barreto SLT. Tabelas brasileiras para aves e suínos: composição de alimentos e exigências nutricionais. 2 ed. Viçosa: Universidade Federal de Viçosa; 2005

SAS INSTITUTE. Statistical Analysis System: user's guide. Version 9.1 ed Cary; 2006.

Silva RG. Farmacocinética e determinação de resíduos de enrofloxacina seu metabólico em tecidos de frangos [doutorado]. Campinas (SP): Universidade Estadual de Campinas; 2004 
Simon A, Schwabe M, Bergner $H$. Glycerol supplementation to broiler rations with low crude protein content. Archive of Animal Nutrition $1997 ; 50: 271-282$

Summers JD, Leeson S, Spratt D. Yield and composition of edible meat from male broilers as influenced by dietary protein level and amino acid supplementation. Canadian Journal of Animal Science 1988;68:241248. 